\title{
UJI EFEKTIFITAS BIOLARVASIDA EKSTRAK ETANOL BUAH LAMPESU (Baccaurea lanceolata) TERHADAP LARVA INSTAR III Culex quinquefasciatus
}

\author{
Dea Alfani Nandjan ${ }^{1}$ \\ ${ }^{1}$ Program Studi Pendidikan Dokter, Fakultas Kedokteran, Universitas Palangkaraya, Palangkaraya \\ Email: Dea.alfani03@gmail.com
}

\begin{abstract}
Filariasis is chronic infection disease caused by worm and carried by Culex quinquefasciatus mosquito. One of the ways to controlling mosquitoes vectors are use biolarvacide or chemical insecticide. Chemical insecticide causing resistance Culex quinquefasciatus larvae and toxic for human. This research aim to determine the biolarvacide effectiviteness of ethanol extract lampesu fruit (Baccaurea lanceolata) to Culex quinquefasciatus larvae instars III. This study was true experimental with a Post test-only control group design. This study used 700 larvae instars III of Culex quinquefasciatus divided into 7 groups consentration of $0,2 \%, 0,4 \%, 0,6 \%, 0,8 \%$ and $1 \%$, the positive control (abate) and negative control (aquadest). The observation was did after treatment in 3 hours, 6 hours, 12 hours and 24 hours. The experiment is replicated four times. At 24 hours exposure concentration of $0,6 \%$ the test larvae mortality reached $38 \%$ and at concentration of $1 \%$ the test larvae mortality reached $30 \%$. In this stuy the concentration of $1,531 \%$ was effective to kill larvae with of 50\% mortality(LC50) and concentration of 10,729\% was effective to kill larvae with of $90 \%$ mortality(LC90). Ethanol Ekstract of Lampesu Fruit (Baccaurea lanceolata) not effective as biolarvacide of Culex quinquefasciatus larvae instars III.
\end{abstract}

Keywords: Lampesu (Baccaurea lanceolata), Biolarvacide, Culex quinquefasciatus, Ethanol Extract.

\section{Abstrak}

Filariasis adalah penyakit menular yang disebabkan oleh cacing yang terdapat pada vektor nyamuk Culex quinquefasciatus. Cara pengendalian vektor nyamuk adalah penggunaan biolarvasida atau insektisida kimia. Penggunaan insektisida kimia menyebabkan terjadinya resistensi terhadap larva Culex quinquefasciatus dan toksik bagi manusia. Penelitian ini bertujuan untuk mengetahui efektifitas biolarvasida ekstrak etanol buah lampesu (Baccaurea lanceolata) terhadap Larva Instar III Culex quinquefasciatus. Penelitian ini adalah True experimental dengan rancangan Post test-only control group design. Penelitian ini menggunakan 700 larva instar III Culex quinquefasciatus yang dibagi menjadi tujuh kelompok konsentrasi yaitu $0,2 \%, 0,4 \%, 0,6 \%, 0,8 \%, 1 \%$, kontrol positif (abate) dan kontrol negatif (aquades). Pengamatan dilakukan pada waktu 3 jam, 6 jam, 12 jam, dan 24 jam. Penelitian ini dilakukan pengulangan sebanyak 4 kali. Pengamatan 24 jam larva pada konsentrasi $0,6 \%$ kematian larva uji mencapai $38 \%$ larva dan pada konsentrasi $1 \%$ kematian larva uji mencapai 30\%. Pada penelitian ini konsentrasi yang efektif membunuh 50\% (LC50) larva adalah sebesar 1,531\% dan konsentrasi yang efektif membunuh 90\% (LC90) larva adalah sebesar 10,729\%. Kesimpulan: Ekstrak Etanol Buah Lampesu (Baccaurea lanceolata) tidak efektif sebagai biolarvasida Larva Instar III Culex quinquefasciatus.

Kata Kunci: Lampesu (Baccaurea lanceolata), Biolarvasida, Culex quinquefasciatus, ekstrak etanol. 


\section{PENDAHULUAN}

Penyakit yang ditularkan melalui nyamuk pada negara berkembang seperti Indonesia sampai sekarang masih menjadi kasus yang mendapat perhatian khusus, karena dampak yang diakibatkan berupa kecacatan sampai menimbulkan kematian. Contohnya adalah penyakit Demam Berdarah, Malaria, dan Filariasis atau yang lebih dikenal dengan penyakit Kaki Gajah. Filariasis termasuk dalam Penyakit Menular Tropik Terabaikan (Neglected Tropical Disease) yang merupakan salah satu prioritas Program Pembangunan Kesehatan Republik Indonesia tahun 2015-2019.1

Filariasis ditandai dengan limfangitis, terjadinya varises saluran limfe, elefantiasis, hidrokel, dan urine berwarna putih susu. 2

Enam puluh persen penduduk di Asia Tenggara tercatat terinfeksi Filariasis. Berdasarkan profil kesehatan Indonesia, prevalensi kejadian Filariasis menunjukan peningkatan setiap tahunnya. Pada tahun 2009 dilaporkan sebanyak 11.914 kasus, tahun 2012 terdapat 11.903 kasus, tahun 2014 terdapat 14.932 kasus, pada tahun 2017 terdapat 12.677 kasus filariasis yang tersebar di 34 Provinsi. Di provinsi Kalimantan Tengah tercatat pada tahun 2013 terdapat 238 kasus Filariasis. Pada tahun 2014 terdapat 227 kasus Filariasis yang tersebar di 14 kabupaten. Tercatat daerah yang memiliki prevalensi penyakit Filariasis tertinggi di Kalimantan Tengah adalah Kotawaringin Timur yaitu sebanyak 157 kasus Filariasis.2

Filariasis disebabkan oleh mikrofilaria Wuchereria bancrofti (Filariasis bancrofti), Brugia malayi dan Brugia timori (Filariasis brugia). Penyakit ini penularannya diperantarai oleh vektor nyamuk Culex sp. melalui limfatik pada manusia. Spesies yang sering menginfeksi manusia adalah Culex quinquefasciatus. Keadaan lingkungan sangat berpengaruh terhadap transmisi Filariasis. Biasanya daerah endemis habitat vektor nyamuk Culex quinquefaciatus bervariasi, antara lain berupa genangan air yang kotor seperti rawa-rawa dan selokan kotor yang sangat potensial untuk perkembangbiakan nyamuk ini. Daerah rawa-rawa terutama lahan gambut yang banyak terdapat di daerah Kalimantan Tengah dan sekitarnya.3

Di Indonesia upaya pemberantasan Filariasis dilaksanakan sejak tahun 1975. Pada tahun 1997, World Health Assembly menetapkan resolusi "Elimination of Lymphatic Filariasis as a Public Health Problem", yang kemudian pada tahun 2000 diperkuat dengan keputusan World Health Organization (WHO) dengan mendeklarasikan "The Global Goal of Elimination of Lymphatic Filariasis as a Public Health Problem by the Year 2020".4 Sehingga telah diprogramkan tindakan 
pemberian insektisida pembasmi larva (larvasida), sebagai tindakan preventif yang dilakukan untuk memberantas wabah nyamuk. Pemberantasan larva dianggap lebih efektif untuk dilakukan dari pada pemberantasan nyamuk dewasa. Nyamuk dewasa bias terbang berpindah-pindah, sedangkan larva berada di tempat perindukan. Larvasida yang sering digunakan di Indonesia adalah Abate (Temephos). Abate menimbulkan bau yang kurang sedap. Penggunaan terlalu sering insektisida yang bersifat kimia seperti Temephos juga dapat menyebabkan pencemaran lingkungan karena sulit terurai di dalam tanah dan terjadinya resistensi insektisida tingkat sedang. Oleh karena itu perlu diteliti alternatif lain yang lebih efektif dan cepat, yaitu diperlukan larvasida nabati (biolarvasida) yang bersifat aman dan mudah terurai di lingkungan.5

Dalam penelitian sebelumnya membuktikan Uji Daya Bunuh Ekstrak Daun Nerium oleander L. Terhadap Larva Nyamuk Aedes aegypti dan Culex quinquefasciatus dengan kandungan aktifnya berupa Saponin, Alkaloid, Tannin, Fenolik, Flavonoid, Dan Steroid.6 Penulis tertarik untuk meneliti tumbuhan lain yang dapat berpotensi sebagai biolarvasida yang dikenal masyarakat Kalimantan Tengah memiliki banyak kegunaan terutama sebagai antibakteri untuk Propionibacterum acnes, buah ini juga memiliki sifat asam, memiliki aktifitas antioksidan dan memiliki kandungan aktif hampir serupa dengan tumbuhan pada penelitian sebelumnya. Tumbuhan yang memiliki potensi sebagai biolarvasida Culex quinquefasciatus adalah buah Lampesu (Baccaurea lanceolata) yang tumbuh di Kalimantan Tengah di daerah hutan kabupaten Katingan, tepatnya di Desa Tewang Kadamba. Berdasarkan pemeriksaan fitokimia buah Lampesu memiliki komponen bioaktif yaitu Alkaloid, Flavanoid, Tannin dan Saponin.7

\section{BAHAN DAN METODE}

Bahan yang diperlukan adalah Alat Maserasi, Nampan plastik ukuran $30 \times 15 \mathrm{~cm}$, Alat pemotong buah Lampesu, Kertas Coklat, Oven , Blender, Toples (wadah), Labu destilasi, Neraca analitik, Cawan petri $250 \mathrm{ml}$, Corong gelas, Gelas ukur, Tissue, Air mengalir, Kertas label, Etanol 70\%, Buah Lampesu yang berasal dari desa Tewang Kadamba yang diambil pada bulan Agustus 2019, Aquadest, Abate, Larva Culex quinquefasctiatus instar III.

\section{Ekstraksi buah Lampesu}

Buah lampesu (Baccaeau lanceolata) dipilih yang kondisi baik sudah tua, berwarna kuning kecoklatan dan masih segar dan tidak busuk. Buah dicuci bersih dan dipotong potong kecil 
dan tipis, dipisahkan dengan bijinya, lalu dikeringkan menggunakan kain hitam.

Setelah kering, buah lampesu dihaluskan menggunakan blender menjadi simplisia.Kemudian dilakukan maserasi dengan pelarut etanol $70 \%$ dengan suhu ruangan selama 3×24 jam, filtrate dipekatkan menggunakan rotary evaporator sehingga didapatkan ekstrak kental

Stok larutan ekstrak buah Lampesu

Stok ekstrak etanol buah Lampesu yang dibuat adalah 5\%. Timbang 5 gram ekstrak kental buah lampesu. Tambahkan dengan aquadest sampai volumenya menjadi $100 \mathrm{ml}$.

Pembuatan Konsentrasi Ekstrak buah Lampesu

Menyiapkan stok larutan yang dibuat sebelumnya. Lakukan perhitungan konsentrasi dengan rumus (dapat dilihat pada lampiran):

Keterangan :

$\mathrm{V}_{1}$ : Volume larutan yang akan diencerkan $(\mathrm{ml})$

$\mathrm{C}_{1}$ : Konsentrasi ektsrak buah Lampesu dalam stok larutan $(\%)$

$\mathrm{V}_{2}$ : Volume larutan (air + ekstrak buah Lampesu) yang diinginkan (ml)
$\mathrm{C}_{2}$ : Konsentrasi ekstrak buah Lampesu yang akan dibuat $(\%)$

Menambah konsentrasi ekstrak yang dibuat dari stok larutan dan menambah dengan aquadest sampai menajdi $100 \mathrm{ml}$.

Persiapan larva Culex quinquefasciatus

Telur nyamuk didapatkan dari Balai Litbangkes Tanah bumbu. Telur diletakkan didalam nampan berisi air dan ditunggu sampai menetas sampai berumur 3-4 hari.

Tahap Perlakuan

Menyiapkan alat dan bahan

Menyiapkan larva Culex quinquefasciatus instar III sebanyak 25 ekor kedalam tiap wadah dan dilakukan pengulangan perlakuan sebanyak 4 kali Menyiapkan ekstrak buah Lampesu dengan konsentrasi yang sudah diatur dan dimasukan ke dalam wadah tempat perlakuan larva. Peneliti menggunakan Alat Pelindung Diri

Pengujian Biolarvasida Ekstrak buah Lampesu

Tahap perlakuan terbagi menjadi pembagian empat waktu, yaitu pada masing-masing waktu perlakuan diberi jarak selama 30 menit : perlakuan pertama diujikan kelompok 1 dan kelompok 2 beserta replikasinya, perlakuan kedua diujikan kelompok 3 dan kelompok 4 beserta replikasinya, perlakuan ketiga 
diujikan kelompok 5 dan kelompok 6 beserta replikasinya, perlakuan keempat diujikan kelompok 7 beserta replikasinya, Masukan larva sebanyak 25 ekor ke dalam wadah perlakuan yang sudah berisi ekstrak dengan masing-masing konsentrasi dengan menggunakan pipet larva, Larva didiamkan dan dilakukan pengamatan secara berulang setelah 3 jam, 6 jam, 12 jam dan 24 jam sesuai dengan waktu dimulainya perlakuan pada masing-masing kelompok. Larva diberi makanan berupa ragi halus yang dilarutkan di dalam air dengan perbandingan 10mg/l sebanyak 1-2 tetes setiap waktu pengukuran. Amati pergerakan larva dalam waktu pengamatan di atas

\section{Pengolahan Lethal Concentration}

Mencatat jumlah larva yang mati selama waktu pengukuran menggunakan Hand Tally Counter dan tabel pencatatan kematian larva (lampiran). Menghitung rata-rata kematian larva pada setiap konsentrasi ektrak pada perlakuan yang dilakukan

Menentukan persentase kematian larva

Melakukan analisa terhadap konsentrasi yang mematikan larva $>50 \%$ dan $90 \%$ dari jumlah larva yang diuji coba.

Tahap terakhir

Larva nyamuk yang sudah selesai digunakan dalam penelitian dikumpulkan dalam wadah besar Larva direndam menggunakan air panas 70 oC selama minimal 5 menit

Jika larva sudah dipastikan mati, larva dikubur didalam tanah sedalam $30-50 \mathrm{~cm}$ dibawah tanah.

Teknik Analisis data

Analisa Uji Varian

Setelah dilakukan pengukuran efektifitas biolarvasida ekstrak etanol buah Lampesu (Baccaurea lanceolata) terhadap larva nyamuk Culex quinquefasciatus. Dari setiap masingmasing konsentrasi ekstrak beserta pengulangannya, maka setiap konsentrasi diakumulasikan jumlah mortalitas larva dan waktu larva yang mati pada setiap konsentrasi dan waku pengukurannya. Data yang diperoleh dalam penelitian ini akan ditabulasikan, yang selanjutnya dianalisis dengan SPSS 22. Data diuji normalitas menggunakan uji normalitas Saphiro Wilk karena menggunakan sampel kurang dari 50. Lalu data dianalisa menggunakan uji nonparametrik Kruskal-Wallis. Berdasarkan uji Kruskal-Wallis dengan nilai $\mathrm{p}<0,05.26$

\section{HASIL DAN PEMBAHASAN}

Hasil Uji Determinasi

Proses dalam menentukan jenis tumbuhan secara spesifik adalah proses determinasi tanaman. Determinasi bertujuan untuk mendapatkan suatu spesies dari tanaman 
sehingga tepat sasaran dalam pemanfaatannya. Tanaman lampesu (Baccaurea lanceolata) dideterminasi di Laboratorium Balai Penelitian dan Konservasi, Lembaga Ilmu Pengetahuan Indonesia (LIPI) Purwodadi.

\section{Hasil Uji Fitokimia}

Berdasarkan hasil skrining fitokimia pada penelitian ini yang dilakukan di Laboratorium Fakultas Kedokteran Universitas Lambung Mangkurat, Ekstrak Etanol Buah Lampesu (Baccaurea lanceolata) mengandung senyawa aktif Saponin, Alkaloid, Flavanoid.

\section{Hasil Pengamatan Morfologi}

Pada hasil pengamatan gambar a didapatkan morfologi larva Culex quiquefasciatus yaitu mempunyai 10 segmen yang terdiri dari kepala (a), thorax (b) , abdomen (c) dan terdapat sifon (d) yang panjang dan telur Culex quinquefasciatus berbentuk seperti ampul obat dan melekat satu sama lain. Pada gambar b dan c adalah gambaran perbandingan morfologi larva yang belum diberikan perlakuan dan sesudah diberikan perlakuan selama 24 jam.

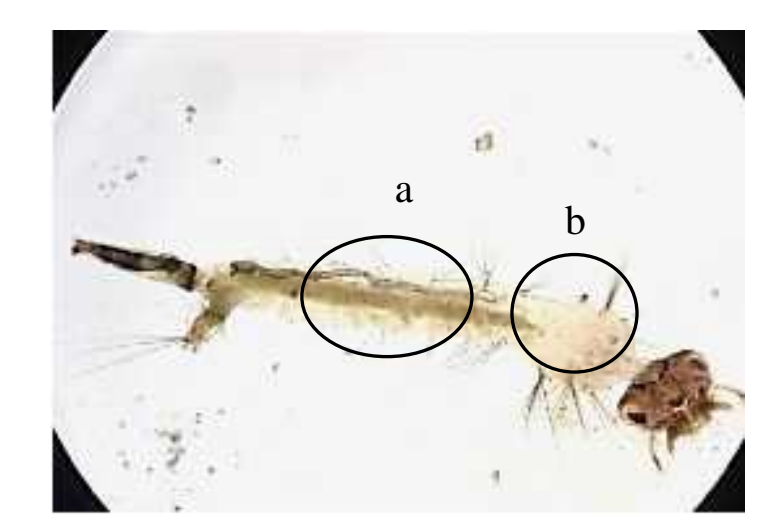

\section{PEMBAHASAN}

Penelitian ini menggunakan tumbuhan buah lampesu (Baccaurea lanceolata) sebagai bahan uji yang telah dilakukan determinasi di Lembaga Ilmu Pengetahuan Indonesia (LIPI) Purwodadi. Hasil determinasi dapat dibuktikan dengan sertifikat hasil uji nomor : 1194/IPH.06/HM/XI/2019 sehingga peneliti dapat menghindari kesalahan pemilihan 
spesies tumbuhan pada penelitian yang dilakukan.

Pada penelitian diketahui bahwa morfologi larva Culex quiquefasciatus yaitu mempunyai 10 segmen yang terdiri dari kepala, thorax, abdomen dan terdapat sifon yang panjang dan bulu sifon 3 pasang serta segmen anal pada ekor. Hal ini sesuai dengan teori bahwa morfologi larva Culex quinquefasciatus memiliki sifon panjang dan bulu sifon lebih dari 1 pasang. Larva yang digunakan adalah larva instar III didapatkan saat penelitian larva berukuran 4-5 mm dan morfologi sudah lengkap serta badan larva berwarna coklat kehitaman.

Pada tabel 5.1 menunjukan hasil fitokimia kandungan senyawa pada Buah Lampesu (Bacccaurea lanceolata) memiliki kandungan yang dapat digunakan sebagai biolarvasida yaitu: Saponin, Alkaloid, Flavanoid, Steroid, dan Tannin. Saponin memiliki efek gangguan tahap perkembangan dan gangguan pergantian kulit (molting) dan menyebabkan kematian karena kehilangan banyak cairan tubuh, saponin juga dapat menurunkan tegangan permukaan selaput mukosa saluran pencernaan larva karena bersifat korosif. Alkaloid mendegradasi membran sel dan kutikula untuk masuk ke dalam dan merusak sel dan juga dapat mengganggu sistem kerja saraf larva dengan menghambat kerja enzim asetilkolinesterase sehingga terjadi perubahan warna pada tubuh larva menjadi lebih transparan dan gerakan tubuh larva yang melambat bila dirangsang. Flavonoid menyebabkan vasokonstriksi yang berlebihan, sehingga permeabilitas rongga badan pada larva menjadi rusak dan hemolimfe tidak dapat didistribusi secara sempurna dan menyebabkan kematian pada larva. Steroid dapat menghambat proses pergantian kulit pada larva.Tannin berperan sebagai larvasida dalam mencerna makanan (stomach poisons) karena tanin akan mengikat protein usus dan akan menghambat enzim pencernaan sehingga menghambat pertumbuhan larva menyebabkan kematian pada larva.

Berikut adalah perbandingan gambaran larva sebelum dan sesudah diberikan perlakuan. Dapat dilihat pada gambar 5.4 tubuh larva setelah perlakuan 24 jam. Larva menjadi transparan dan rusak yaitu karena rusaknya kutikula pada tubuh larva (a) akibat efek larvasida yang bekerja pada tubuh larva yaitu alkaloid, steroid, dan saponin. Saluran pencernaan larva mulai tidak utuh (a) dan mengalami kerusakan akibat terpapar saponin dan tannin yang korosif pada saluran pencernaan larva dan akan menghambat pertumbuhan larva ke tahap perkembangan selanjutnya yaitu pupa dan nyamuk dewasa. Morfologi larva juga sudah tidak lengkap seperti sebelum dimulai perlakuan, dapat dilihat bulu bulu pada tubuh larva (b) 
jumlahnya tidak seperti larva yang sebelum perlakuan akibat rusaknya kutikula pada tubuh larva. (dapat dilihat pada gambar 5.3)

Pada tabel 5.4 diketahui mortalitas larva pada kontrol positif (abate) sebesar 100\%, hal ini disebabkan karena abate (temephos) sebagai stomach poison yang termakan oleh larva mempunyai cara kerja menghambat enzim kolinesterase, sehingga menimbulkan gangguan pada aktivitas saraf karena tertimbunnya asetilkolin pada ujung saraf. Fungsi dari enzim kolinesterase adalah menghidrolisa asetilkolin menjadi kolin dan asam cuka, sehingga bila enzim tersebut dihambat maka hidrolisa asetilkolin tidak terjadi sehingga otot akan tetap berkontraksi dalam waktu lama maka akan terjadi kekejangan dan kematian larva sehingga abate membunuh larva dalam waktu singkat. Penetrasi abate ke dalam larva berlangsung sangat cepat, keracunan fosfat organic pada serangga diikuti tremor dan konvulsi kemudian kelumpuhan otot (paralisa), yang menyebabkan larva tenggelam dan mati karena tidak dapat mengambil udara untuk bernafas. Abate sebagai larvasida sintetis (kimiawi) diketahui masih memiliki efektifitas terhadap larva instar III Culex quinquefasciatus.

Hasil Uji Normalitas pada tabel 5.5 terhadap jumlah kematian larva Culex quinquefasciatus pada setiap kelompok konsentrasi dengan waktu didapatakan hasil sebaran data yang tidak normal data dari konsentrasi $0,2 \%$ yaitu $\mathrm{p}=0,717(\mathrm{p} \searrow 0,05)$, konsentrasi $0,4 \%$ yaitu $\mathrm{p}=0,276 \quad(\mathrm{p} \searrow 0,05)$, konsentrasi $0,6 \%$ nilai $\mathrm{p}=0,951(\mathrm{p} \searrow 0,05), \quad$ konsentrasi $0,8 \%$ nilai $\mathrm{p}=0,424 \quad(\mathrm{p} \searrow 0,05) \quad$ dan konsentrasi $1 \%$ $\mathrm{p}=0,911(\mathrm{p} \oslash 0,05)$, aquadest $=0,001(\mathrm{p}<0,05)$, dan Abate $=0,001 \quad(\mathrm{p}<0,05)$ maka dinyatakan sebaran data tidak normal. Uji Hipotesis dilanjutkan dengan Uji Kruskall-wallis pada lampiran 11 menunjukan nilai $\mathrm{p}=0,218$ ( $p \geq 0,005$ ) maka dinyatakan Ho diterima dapat dinyatakan bahwa tidak ada perbedaan yang bermakna antara kenaikan konsentrasi ekstrak etanol buah lampesu dan jumlah kematian larva Culex quinquefasciatus. Merujuk dari kedua hasil uji statistik yang telah dilakukan, bisa dikatakan bahwa ekstrak etanol buah lampesu (Baccaurea lanceolata) tidak efektif sebagai biolarvasida larva Culex quinquefasciatus. Hal ini disebabkan oleh pemberian makanan pada larva, faktor lainnya, dan waktu paparan hanya 24 jam. Pada penelitian ini larva uji diberikan makanan berupa fish food karena mencegah larva mati akibat kelaparan. Menurut WHO 2005 pada Guidelines for Laboratory and Field Testing of Mosquito Larvicides sebaiknya makanan larva diberikan jika melakukan pengamatan long exposure atau diatas 24 jam. 
Menurut teori Lethal Concentration 50 (LC50) adalah konsentrasi yang dapat menyebabkan kematian $50 \%$ dari populasi hewan uji. Menurut WHO 2005 pada jika hasil pengamatan didapatkan hasil mortalitas larva $10 \%$ - 90\% maka dikatakan memiliki efek kematian pada larva uji dan dapat dilanjutkan pengujian Lethal Concentration 50 dan 90. Dari data kematian yang didapat, pada 24 jam perlakuan diketahui hasil mortalitas larva paling tinggi dengan konsentrasi $0,6 \%$ sebesar $38 \%$ sedangkan untuk konsentrasi $1 \%$ sebesar $30 \%$. Menurut hasil uji Analisa Probit didapatkan hasil LC50 pada ekstrak buah lampesu adalah 1,531\% dan nilai LC90 adalah 10,729\% yang artinya dibutuhkan konsentrasi sebesar 1,531\% untuk membunuh sebanyak 50\% larva Culex quinquefasciatus dan konsentrasi sebanyak 10, 729\% untuk membunuh sebanyak 90\% larva Culex quinquefasciatus. Suatu zat dikatakan aktif atau toksik pada uji insektisida dengan konsentrasi maksimal 1000 ppm jika memiliki LC50 < 500 ppm. Konsentrasi $1,531 \%$ (15.310 ppm) sebagai nilai LC50 dan konsentrasi 10,729\% (107.290 ppm) sebagai LC90 menjelaskan bahwa penggunaan ekstrak etanol buah lampesu sebagai larvasida tidak toksik terhadap larva instar III Culex quinquefasciatus.

\section{KESIMPULAN DAN SARAN}

\section{Kesimpulan}

Dari penelitian yang telah dilakukan dapat ditarik kesimpulan bahwa:

Diketahui kandungan yang terdapat dalam buah lampesu (Baccaurea lanceolata) adalah senyawa aktif Saponin, Alkaloid, Flavanoid, Steroid, dan Tannin.

Ekstrak etanol Buah Lampesu (Baccaurea lanceolata) pada konsentrasi 0,2\%, 0,4\%, $0,6 \%$ dan $0,8 \%$ dan $1 \%$ tidak efektif sebagai larvasida pada larva Culex quinquefasciatus.

Lethal Concentration (LC50) didapatkan pada konsentrasi $1,531 \%$ setelah waktu pengamatan 24 jam.

Lethal Concentration (LC90) didapatkan pada konsentrasi $10,729 \%$ setelah waktu pengamatan 24 jam.

\section{DAFTAR PUSTAKA}

1. Departemen Kesehatan RI .2018. Infodatin Pusat Data dan Informasi Kesehatan RI "Menuju Indonesia Bebas Filariasis".Jakarta.

2. Meliyanie G, Andiarsa D. Studi Literatur .2017. Program Eliminasi Lymphatic Filariasis di Indonesia. Journal of Health Epidemiology Communicable Disease. Hal 63-70. 
3. Sutanto I, Ismid S, Pudji K, Sungkar S. 2008. Buku Ajar Parasitologi Kedokteran. Edisi 4. Jakarta: Balai penerbit FK UI. hal. 260

4. Peraturan Menteri Kesehatan Republik Indonesia Nomor 94 Tahun 2014 Tentang Penanggulangan Filariasis.

5. Tawatsin, A., Steve D. W., Rederic, S., Thavara, U., Techadamrongsin, Y., 2001. Repellencyof Volatile Iols From Plant Againt Three Mosquito Vectors.Journal of Vector Ecology.26(1): 76-82.

6. Isnawati R, Murni, Nelfita. 2015. Jurnal Vektor Penyakit : Uji Daya Bunuh Ekstrak Daun Nerium oleander L. Terhadap Larva Nyamuk Aedes aegypti dan Culex quinquefasciatus. Balai Litbangkes P2B2 Donggala

7. Lim, T. K "Baccaurea Lanceolata. 2012" Edible Medicinal And Non-Medicinal Plants, vol. 12, no. 02, doi:10.1007/97894-007-4053-2_31.

8. M. Susanti, H. Kuncoro, and L. Rijai.2018. "Uji Aktivitas Larvasida Ekstrak Daun Keladi Birah (Alocasia indica Schott) Terhadap Larva Nyamuk Culex sp.," J. Sains dan Kesehat., vol. 1, no. 1 , pp. $5-10$

9. Nurlaela $S$, Putri $Y$, Haris $M$, Ferdiansyah R, Nurhayati R, Sari Y P .2018. PHARMACY : Aktivitas Antibakteri Ekstrak Etanol Buah, Daun, Dan Kulit Batang Limpasu (Baccaurea lanceolata (Miq.) Müll.Arg.) Dari Kalimantan Selatan. Vol.15 No. 02. Fakultas Farmasi FK UI

10. Kuncoro H.2013. Aktivitas larvasida Ekstrak Daun Tumbuhan Mara Tunggal (Clausena excavate brum.f) dan daun Zodia (Euodia ridleyi hochr) terhadap larva nyamuk Culex sp.Fakultas Farmasi Universitas Mulawarman

11. Pratama R A.2016. Ekstrak Daun Rambutan \{Nephelium lappaceum L.) terhadap Larva Culex quinquefasciatus.Fakultas Kedokteran Universitas Muhammadyah Palembang

12. WHO. 2013. Global Programme To Eliminate Lymphatic Filariasis, Practical Enthomology. WHO

13. Dharmawan, R. 1993. Metoda Identifikasi Spesies Kembar Nyamuk Anopheles. Sebelas Maret University Press, Surakarta

14. Center for Disease Control and Prevention (CDC) 2012. Body Mass Index: Considerations for Practitioners. $1-4$

15. Mosquito Information Website. (2009). University of Florida, Florida Medical Entomology Laboratory. (19 April 2019)

16. Prianto J, Tjahaya dan Darwanto. 2006. Atlas Parasitologi Kedokteran. Jakarta : Gramedia Pustaka Utama 
17. Soegijanto,S. 2003. Demam Berdarah Dengue, Tinjauan dan Temuan Baru di Era 2003.

18. Borror, 1992. Pengenalan Pelajaran Serangga, edisi VI. Yogyakarta: Gajah Mada University Press

19. Haryono. 2011. Konsep dan Strategi Penelitian dan Pengembangan Pestisida Nabati. Prosiding Seminar Nasional Pesnab IV: Jakarta

20. Effendi, H. 2003. Telaah kualitas air. Kanisius. Yogyakarta.

21. Sembel, Dantje Terno. 2015. Toksikologi Lingkungan.Yogyakarta.

Penerbit Kanisius

22. Matsumura F. (1975) Entry of Insecticides into Animal Systems. In: Matsumura F. (eds) Toxicology of Insecticides. Springer, Boston, MA

23. Djojorsumarto, parut.2008. Pestisida dan aplikasinya Jakarta. Agromedia Pustaka

24. World Health Organization.1992. Vector resistance to pesticides: fifteenth report of the WHO expert committee on vector biology and control. WHO Technical Report Series 818, Geneva.

25. World Health Organization. Handbook for integrated vector management. Outlooks Pest Manag. 2012;24(3):1-78. doi:10.1564/v24_jun_14.

26. Kardinan, Agus. 2000. Pestisida Nabati: Ramuan dan Aplikasi, Penebar Swadaya, Jakarta.
27. Tennyson, S., Samraj, D. A., Jeyasundar, D., Chalieu, K., College, M. C., \& Nadu, T. 2013. Larvicidal Efficacy of Plant Oils Against the Dengue Vector Aedes aegypti ( L .) ( Diptera : Culicidae ). Middle-East Journal of Scientific Research, 13(1), 64- 68

28. Lim, T. K.,.2012. "Baccaurea Lanceolata." Edible Medicinal And NonMedicinal Plants, vol. 4, Springer

29. Shivakumar, M.S., Srinivasan, R., dan Natarajan, D. 2013. Larvacidal Potential of Some Indian Medical Plant Extracts Against Aedes aegypti. Asian Journal of Pharmaceutical and Clinical Research Vol. 6

30. Chintia T.2015. Efek Larvasida Ekstrak Daun Cengkeh (Syzygium aromaticum L.) terhadap Aedes Aegypti. Fakultas Kedokteran Lampung

31. Santana, C.M., Z.S. Ferrera, M.E.T. Padron, and J.J.S. Rodriquez. 2009. Methodologies for The Extraction of Phenolic Compounds from Enviromental Samples : New Approaches. Molecules. Vol. 14. Hal. 298- 320.

32. Palant J. 2013. SPSS : A Step by guide to data analysis using IBM SPSS. Edisi V.Sydney, Melbourne.

33. Dahlan, M.Sopiyudin. 2008. Langkah Langkah Membuat Proposal Penelitian Bidang Kedokteran dan Kesehatan. Jakarta. CV Agung Seto 
34. WHO. 2005. "Guidelines for Laboratory and Field Testing of Mosquito Larvicides. "

35. Departemen Kesehatan RI. Parameter Standar Umum Ekstrak Tumbuhan Obat. Cetakan Pertama. Jakarta: Depkes RI. 2000. Hal: 3-11.

36. Ndung'u., Torto, Knols., B ., \& Hassanali, A(2004). Laboratory evaluation of some eastern African Meliaceae as sources of larvacidal botanicals for anopheles gambiae. International Jounal of Tropical Insect Sciense, 24(\$), 311-318. 